\author{
PaWet Marszatek
}

\title{
KONKURENCJA WALUTOWA I JEJ NASTĘPSTWA
}

\section{WSTĘP}

W pierwszej połowie XIX wieku Anglia jako pierwszy kraj na świecie zakończyła budowę homogenicznego systemu pieniężnego. Wyeliminowano wówczas wielość znajdujących się w obiegu rodzajów pieniądza, umacniając tym samym monopol banku Anglii jako podmiotu emitującego i regulującego pieniądz. Podobny proces dokonał się w ciągu następnych dekad w większości rozwiniętych państw ${ }^{1}$.

Tym samym ograniczeniu uległa konkurencja, jaką dla jednostek, będących w poszczególnych krajach prawnym środkiem płatniczym, stanowiła cała gama prywatnych jednostek pieniężnych (w tym odmiany pieniądza lokalnego) oraz jednostki pieniężne innych krajów. Poszczególne państwa, za pomocą banków centralnych, zaczęły odgrywać nadrzędną rolę w kreacji i regulacji pieniądza.

Monopol państwa w sferze monetarnej umacniał się po II wojnie światowej. Charakterystyczny dla ówczesnej (a także współczesnej) gospodarki stał się model systemu pieniężnego, w którym funkcjonuje pieniądz państwowy jako prawny środek płatniczy ${ }^{2}, z$ dominującym bankiem centralnym, mającym wyłączne prawo emisji pieniądza gotówkowego i wpływającym na kreację pieniądza bezgotówko-

${ }^{1}$ E. Gilbert, E. Helleiner, Introduction - Nation-states and money. Historical contexts, interdisciplinary perspectives, [w:] Nation-States and Money. The past, present and future of national currencies, eds. E. Gilbert, E. Helleiner, Routledge, London-New York 2002, s. 3. Była to część szerszego procesu formowania się państwa narodowego. Wśród przyczyn takiej przebudowy systemu pieniężnego wymienia się między innymi: większą skuteczność aparatu państwowego, postęp technologiczny, umożliwiający standaryzację procesu emisyjnego, rozbudowę aparatu fiskalnego państwa oraz coraz szerszy zakres usług oferowanych przez państwo, w których możliwe i konieczne było posługiwanie się pieniądzem państwowym (zob. N. Dodd, Globalisation of Money? National Sovereignty and the Management of Risk, [w:] Nation-States and Money. The past, present and future of national currencies, eds. E. Gilbert, E. Helleiner, Routledge, London-New York 2002, s. 183-185).

${ }^{2}$ Jest to przy tym pieniądz fiducjarny, począwszy od 1978 r. niemający nawet formalnie charakteru pieniądza towarowego. 
wego przez podlegające ścisłej regulacji banki ${ }^{3}$. $\mathrm{Na}$ proces konkurencji walutowej nałożono natomiast liczne ograniczenia, znacząco utrudniając posługiwanie się na obszarze danego państwa innymi jednostkami pieniężnymi ${ }^{4}$.

Funkcjonowanie takich systemów budzi jednak liczne zastrzeżenia o charakterze zarówno ekonomicznym, jak i społecznym. W tym pierwszym nurcie krytyki wskazuje się na nadużywanie przez państwo jego monopolu w sferze pieniężnej do osiągania własnych celów. Konsekwencją tego jest „wrodzona” niestabilność systemów pieniężnych tego typu, wyrażająca się zarówno okresami wysokiej inflacji, jak i występowaniem kryzysów finansowych ${ }^{5}$. Wśród problemów natury społecznej wymienia się natomiast pogłębianie nierówności społecznych, szkodliwy wpływ na rozwój lokalnych wspólnot czy osłabianie więzi społecznych ${ }^{6}$.

W kontekście tych zastrzeżeń nasuwa się pytanie, czy dopuszczenie konkurencji w sferze pieniężnej mogłoby wyeliminować chociaż część niedostatków w funkcjonowaniu systemów pieniężnych poszczególnych państw. Kwestia ta jeszcze bardziej zyskuje na aktualności i znaczeniu, gdy uwzględni się zmiany, zachodzące w ciągu ostatnich dwóch dekad w sferze stosunków pieniężnych. Mianowicie, pojawiają się nowe formy i rodzaje pieniądza, a także zarysowują się nowe lub intensyfikują się już istniejące trendy w jego rozwoju ${ }^{7}$. Zmienia się też sposób prowadzenia polityki pieniężnej i możliwości banków centralnych w zakresie wpływania na obieg pieniężny i poziom cen.

Efektem tych zjawisk jest nasilenie się konkurencji walutowej. Niekiedy mówi

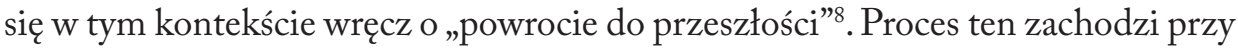

${ }^{3}$ Uznanie prymatu państwa w sferze pieniądza wynikało również z rozwoju określonych teorii ekonomicznych.

${ }^{4}$ Zob. szerzej R. Vaubel, Currency Competition vs Governmental Money Monopolies, „Cato Journal” 1986, vol. 5, no. 3 .

${ }^{5}$ Jak informuje P. Bernholz, od 1970 r. nie było pieniądza państwowego, którego siła nabywcza byłaby stabilna dłużej niż 30 lat (P. Bernholz, The Importance of Reorganizing Money, Credit and Banking when Decentralizing Economic Decisionmaking, [w:] Economic Reform in China: Problems and Prospects, University of Chicago Press, Chicago 1990, s. 103).

${ }^{6}$ Zob. np. B. Lietaer, The Future of Money: Creating New Wealth, Work and a Wiser World, Century, London 2001, s. 187.

${ }^{7} \mathrm{~W}$ historii pieniądza można zasadniczo wyróżnić trzy główne (aczkolwiek nieliniowe) trendy. Pierwszym jest stopniowa dematerializacja pieniądza od form rzeczowych w kierunku coraz bardziej abstrakcyjnych. Drugi trend stanowi coraz większa skuteczność zarządzania relacjami między dłużnikami i kredytodawcami, przede wszystkim w sektorze finansowym. Chodzi tu o ciągłe ulepszanie umów i standardów, zapewniających wzajemne uznawanie oraz rozliczanie zobowiązań międzybankowych. W tym trendzie rysują się dwa przeciwstawne kierunki: tendencja do większej centralizacji zarządzania systemem rozliczeń oraz rosnące możliwości stosowania złożonych, zdecentralizowanych form pieniądza i mechanizmów płatności. Trzecią zauważalną tendencją jest rosnąca skala i znaczenie regulacji (zob. R. Miller, W. Michalski, B. Stevens, The Future of Money, [w:] The Future of Money, OECD, Paryż 2002, s. 11-30).

${ }^{8}$ B. Craig, Competing Currencies - Back to the Future?, Economic Commentary, Federal Reserve Bank of Cleveland 1996, October, 15. 
tym na wielu płaszczyznach, pociągając za sobą liczne następstwa dla poszczególnych państw, ich społeczeństw, a także - najbardziej bezpośrednio - dla banków centralnych.

Celem opracowania jest przybliżenie zjawiska konkurencji walutowej we współczesnej gospodarce, ze szczególnym uwzględnieniem jej następstw. Wskazano przy tym na zalety tej konkurencji, jednak nie poruszono szczegółowo kwestii, czy i na ile konkurencja walutowa faktycznie jest skuteczniejszym rozwiązaniem niż monopol państwa i banku centralnego9. Przedstawiono definicje konkurencji walutowej, jej cechy oraz płaszczyzny, na jakich konkurencja ta może występować. Kolejną część artykułu poświęcono szczególnie kontrowersyjnemu obszarowi konkurencji walutowej, a mianowicie konkurencji, jaką dla pieniądza państwowego, będącego prawnym środkiem płatniczym, stanowić mogą prywatne jednostki pieniężne. W końcu zarysowano wybrane następstwa procesów konkurencji walutowej.

\section{POJĘCIE I PŁASZCZYZNY KONKURENCJI WALUTOWEJ}

Pojęcie konkurencji walutowej nie jest jednolicie formułowane. Najogólniej przez taką konkurencję rozumie się rywalizację między rozmaitymi jednostkami (standardami) pieniężnymi ${ }^{10}$. Ich emitenci dążą do zwiększenia skali posługiwania się przez osoby fizyczne i podmioty gospodarcze konkretną jednostką pieniężną. Im większa ta skala, tym większe korzyści osiąga emitent danej jednostki.

Natomiast według G. Tullocka za konkurencję walutową uważa się sytuację, w której w danym kraju funkcjonuje więcej niż jeden pieniądz, z których żaden nie ma pozycji dominującej ${ }^{11}$. Autor ten zwraca zatem uwagę, że konkurencja musi odbywać się na pewnym obszarze (najczęściej określonego państwa), gdzie ścierają się ze sobą interesy emitentów poszczególnych jednostek pieniężnych. Ma to znaczenie w kontekście swoistej "geografii” pieniądza i jego powiązania bądź oderwania od danego terytorium ${ }^{12}$.

${ }^{9}$ Kwestie te rozważają np. F. A. Hayek (w: Denationalisation of Money, Institute of Economic Affairs, London 2007) i B. Klein (w: The Competitive Supply of Money, "Journal of Money, Credit \& Banking” 1974, vol. 6, no. 4, s. 446-450).

${ }^{10}$ L. H. White, Currency Competition and Consumer-Driven Unification, „Cato Journal” 2003, vol. 23 , no. 1 , s. 139 .

${ }^{11}$ G. Tullock, Competing Monies, „Journal of Money, Credit \& Banking” 1975, vol. 7, no. 4, s. 491-492.

${ }^{12}$ Zob. szerzej E. Helleiner, The Making of National Money. Territorial Currencies in Historical Perspective, Cornell University Press, Ithaca-London 2003. 
Konkurencję walutową niekiedy traktuje się nie tylko jako składnik, swoistą cechę, ale wręcz jako określony typ systemu pieniężnego. Cechuje się on między innymi: swobodą emisji pieniądza przez niepodlegające regulacjom banki prywatne, wielością jednostek pieniężnych znajdujących się w obiegu oraz brakiem banku centralnego lub brakiem jego uprzywilejowanej pozycji w sferze monetarnej. W tym kontekście konkurencja walutowa ściśle wiąże się z tzw. wolną bankowością (free banking) $)^{13}$.

Konkurencja walutowa ma dwa wymiary. Pierwszym z nich jest konkurencja między poszczególnymi narodowymi jednostkami pieniężnymi - przykładowo, między dolarem, jenem, euro, funtem czy innymi walutami. Konkurencję w sferze pieniężnej można tu traktować jako element szerszego procesu budowania pozycji konkurencyjnej danego państwa na arenie międzynarodowej ${ }^{14}$.

Konkurencja ta zasadniczo dotyczy spełniania przez daną jednostkę pieniężna poszczególnych funkcji pieniądza w stosunkach międzynarodowych. Zdaniem B. J. Cohena najważniejszym wskaźnikiem międzynarodowego statusu danego pieniądza i jego silnej pozycji konkurencyjnej jest częstotliwość wykorzystywania w transakcjach na rynkach walutowych (funkcja środka płatniczego). Niemniej, znaczenie ma również skala stosowania określonej jednostki pieniężnej jako waluty rezerwowej (funkcja środka przechowywania wartości), a także jako waluty, w której fakturuje się transakcje (funkcja jednostki obrachunkowej) ${ }^{15}$.

Pieniądz, który uczestnicy transakcji chcą używać do wymienionych celów, ma przewagę konkurencyjną względem innych walut. Popyt na niego jest relatywnie większy niż popyt na inne waluty. Wraz ze wzrostem popytu na tę walutę rośnie też pole działania jej emitenta i korzyści, jakie czerpie on $z$ tej swoistej dominacji własnego pieniądza na rynku finansowym.

Potencjalnym następstwem konkurencji na tej płaszczyźnie może być zjawisko substytucji walutowej (currency substitution). Polega ono na wypieraniu z krajowego obiegu pieniężnego słabej waluty narodowej przez walutę silniejszą. Jest to możliwe w sytuacji, gdy ta pierwsza, z rozmaitych względów (takich jak np. zmniejszająca się szybko siła nabywcza czy niskie zaufanie społeczne do danego pieniądza $)^{16}$, nie spełnia należycie funkcji pieniądza. Wówczas osoby fizyczne

${ }^{13}$ Por. V. Smith, The Rationale of Central Banking and the Free Banking Alternative, Liberty Press, Indianapolis 1990, s. 1; L. H. White, Free Banking in Britain. Theory, Experience and Debate, 1800-1845, $2^{\text {nd }}$ edition, IEA, Londyn 2008, s. 1.

${ }^{14}$ L. H. White nazywa ten proces również „konkurencją między bankami centralnymi” (L. H. White, Currency Competition..., s. 140).

${ }^{15}$ B. J. Cohen, Global Currency Rivalry: Can the Euro Ever Challenge the Dollar?, The Third Journal of Common Market Studies - European Union Studies Association Lecture, Global \& International Studies Program, paper no. 8, University of California 2003, s. 4-5.

${ }^{16}$ Zob. T. D. Willet, K. Banaian, Currency Substitution, Seigniorage and the Choice of Currency Policies, [w:] Macroeconomics of International Currencies, eds. P. Mizen, E. Pentecost, Edgar El- 
i podmioty gospodarcze $\mathrm{z}$ naturalnych względów szukają substytutu, mogącego zaspokoić ich potrzeby w tym zakresie.

Konkurencja między walutami narodowymi nasila się we współczesnym świecie. Wśród przyczyn takiego stanu rzeczy wymienia się na ogół wiele, ściśle powiązanych zjawisk: globalizację, wzrost skali światowego handlu i wiążący się z tym rosnący popyt na płynność, upowszechnianie się innowacji finansowych, znoszenie ograniczeń dewizowych, większą swobodę przepływów kapitałowych i bardzo duży wzrost ich skali, czy wreszcie postęp technologiczny ${ }^{17}$. Wszystkie te czynniki sprawiają, że podejmując decyzje inwestycyjne czy lokacyjne, łatwiej jest wybrać walutę, w której chce się przeprowadzić daną operację, a następnie dokonać transakcji wymiennej. Tańsze i szybsze stało się pozyskanie informacji, a przy tym zwiększyły się możliwości oceny oraz interpretacji poszczególnych informacji.

Skala konkurencji między poszczególnymi walutami może przybrać dość znaczne rozmiary. W jej następstwie, pewne waluty narodowe mogą zostać zmarginalizowane, lub nawet mogą zniknąć. $Z$ drugiej strony, liczba walut w gospodarce światowej systematycznie rośnie, nawet mimo trwających procesów integracyjnych w sferze monetarnej ${ }^{18}$. Co więcej, stale zwiększa się - wskutek nasilenia się wymiany międzynarodowej - popyt na jednostki pieniężne. Nie sprawdziło się zatem postulowane przez wielu ekonomistów zjawisko tzw. kontrakcji walutowej (currency contraction), czyli zmniejszania się liczby walut narodowych ${ }^{19}$. Rodzi to wyzwania dla twórców międzynarodowej architektury finansowej ${ }^{20}$, ale jednocześnie może być korzystne z punktu widzenia uczestników światowej gospodarki i efektywności poszczególnych systemów pieniężnych. Chcąc bowiem zachować pozycję konkurencyjną swojej waluty, rządy poszczególnych krajów muszą pro-

\footnotetext{
gar 1996, s. 77-80. Zjawisko to określa się mianem tzw. dolaryzacji (dollarization), gdyż to właśnie dolar najczęściej przejmował funkcje pieniądza w miejsce słabej waluty danego kraju, której chęć posiadania przez obywateli danego państwa i możliwości jej funkcjonowania w charakterze środka płatniczego i środka wymiany stały się bardzo niskie (L. H. White, Currency Competition..., s. 140-142). Warto zaznaczyć, że zjawisko dolaryzacji wystąpiło również w Polsce w okresie gospodarki centralnie zarządzanej.

${ }^{17}$ Por. R. S. Kroszner, The Conquest of Worldwide Inflation: Currency Competition and Its Implications for Interest Rates and the Yield Curve, Speech given at the Cato Institute's Monetary Policy Conference, Washington, D.C., November 16, 2006.

${ }^{18} \mathrm{Za}$ najbardziej widoczny przejaw tendencji do integracji w sferze pieniężnej można uznać utworzenie obszaru euro. Wspólna waluta zastąpiła w nim już kilkanaście walut narodowych państw europejskich.

${ }^{19}$ Szerzej B. J. Cohen, The Future of Money, Princeton University Press, Princeton-Oxford 2004, s. 1.

${ }^{20}$ Głównie wskutek zwiększonego w takiej sytuacji ryzyka walutowego i potrzeby podjęcia działań, mających sprzyjać jego redukcji.
} 
wadzić zdyscyplinowaną politykę makroekonomiczną i dbać o stabilność systemu finansowego.

Drugą płaszczyzną rozpatrywania konkurencji walutowej jest swoista rywalizacja wewnątrz danego państwa. Konkurencję tę można nazwać subnarodową21. Zachodzi ona między pieniądzem mającym status prawnego środka płatniczego a różnymi rodzajami tzw. pieniądza prywatnego. Mimo monopolu państwa w sferze monetarnej, w coraz większej liczbie krajów prywatne jednostki pieniężne (emitowane przez duże korporacje lub/i wspólnoty lokalne ${ }^{22}$ ) zaczynają odgrywać coraz większą rolę, będąc przy tym wyrazem swoistych tendencji decentralizacyjnych i antyglobalizacyjnych. Dzieje się tak mimo znaczącej asymetrii w potencjałach emitentów pieniądza państwowego i prywatnego.

Należy podkreślić, że na obu rozważanych w tym punkcie płaszczyznach konkurencji walutowej jednostka pieniężna, będąca w danym państwie prawnym środkiem płatniczym, jest konfrontowana $z$ konkurencyjnymi jednostkami pieniężnymi. Charakterystyczne jest, że pierwsza z rozważanych płaszczyzn, czyli konkurencja narodowych jednostek pieniężnych, nie budzi zasadniczo kontrowersji i jest uważana za normalny element rzeczywistości gospodarczej. Inaczej jest w przypadku konkurencji ze strony jednostek pieniężnych emitowanych przez podmioty niepaństwowe. Zjawisko to, mimo dość powszechnego występowania w przeszłości i rosnącego zainteresowania nim wśród ekonomistów w ostatnich latach, ciągle jest relatywnie mało znane. $Z$ funkcjonowaniem prywatnego pieniądza wiążą się też swoiste uprzedzenia ${ }^{23}$. $Z$ tego względu ta płaszczyzna konkurencji walutowej zostanie bliżej scharakteryzowana w następnym punkcie.

\section{KONKURENCJA WALUTOWA NA POZIOMIE SUBNARODOWYM}

Jak podkreśla B. J. Cohen, jeszcze na początku XIX wieku rola sektora prywatnego jako głównego emitenta pieniądza nie była zasadniczo negowana. $\mathrm{Na}$ ogół pieniądz prywatny pojawiał się wówczas, gdy z różnych względów nie spraw-

${ }^{21}$ Zob. E. Helleiner, Conclusion - The Future of National Currencies?, [w:] Nation-States and Money. The past, present and future of national currencies, eds. E. Gilbert, E. Helleiner, Routledge, London-New York 2002, s. 215.

${ }^{22}$ Szacuje się, że w 2009 r. na świecie funkcjonowało ponad 2500 systemów pieniądza lokalnego, http://www.mssresearch.org/?q=Local_Currency (16.10.2009).

${ }^{23}$ Jak się wydaje, jest to głównie efektem utrwalenia się poglądu o negatywnych skutkach funkcjonowania systemów wolnej bankowości, swoistego status quo w kwestii uznania dominacji banku centralnego w systemie pieniężnym i wiążącej się z tym dość powszechnej akceptacji faktu, że to właśnie państwo powinno odgrywać decydującą rolę w systemie pieniężnym, czy wręcz problemów natury konceptualnej i ideologicznej. 
dzał się pieniądz państwowy lub gdy podaż tego pieniądza była zbyt mała ${ }^{24}$. Nie jest to więc zjawisko nowe.

Mimo to istnieje wiele definicji pieniądza prywatnego. Zazwyczaj przez taki pieniądz rozumie się jednostkę, która nie została wyemitowana ani nie jest gwarantowana przez jakikolwiek podmiot rządowy ${ }^{25}$. Można go też określić jako płynne zobowiązanie stworzone celowo przez źródła niepaństwowe (często lokalne), w celu wypełniania standardowych funkcji pieniądza ${ }^{26}$. Natomiast jako formy tego pieniądza wymienia się najczęściej pieniądz lokalny oraz pieniądz elektroniczny ${ }^{27}$.

Zasadniczo występują dwie główne grupy powodów upowszechniania się prywatnego pieniądza. Obie nawiązują do korzyści, wiążących się z posługiwaniem się tym pieniądzem. Do grupy pierwszej zalicza się argumenty natury czysto ekonomicznej. Natomiast grupa druga obejmuje kwestie o charakterze społecznym.

Jeżeli chodzi o powody ekonomiczne, to podkreśla się na ogół, że system pieniężny opierający się na pieniądzu prywatnym i będącej jego niezbywalnym elementem konkurencji między poszczególnymi jednostkami pieniężnymi, emitowanymi przez prywatne podmioty, byłby bardziej stabilny niż systemy bazujące na pieniądzu państwowym. Konkurencja w sferze walutowej miałaby bowiem podobnie jak konkurencja w odniesieniu do innych, „Zwyczajnych” dóbr - pozytywne następstwa dla mieszkańców danego kraju ${ }^{28}$. Ograniczona zostałaby natomiast aktywność państwa w sferze monetarnej, prowadząca do nadmiernej emisji pieniądza i przyczyniająca się do wzrostu presji inflacyjnej, a także kryzysów finansowych ${ }^{29}$.

Uzasadniając natomiast wprowadzenie i upowszechnienie pieniądza prywatnego z perspektywy korzyści społecznych, przede wszystkim uwzględnia się tę odmianę pieniądza prywatnego, jaką jest pieniądz lokalny. Rozumie się przez niego pieniądz o dość ograniczonym zasięgu, emitowany przez daną społeczność i służący

${ }^{24}$ Najczęściej wymienia się tu trzy sytuacje: dokonywanie transakcji o bardzo małej wartości, zapewnienie płatności w odległych, często odciętych od cywilizacji miejscach oraz sytuacje kryzysu finansowego (B. Champ, Private Money in Our Past, Present and Future, Federal Reserve Bank of Cleveland Economic Commentary, styczeń 2007, s. 1-3).

${ }^{25}$ B. A. Good, Private Money: Everything Old is New Again, Federal Reserve Bank of Cleveland Economic Commentary, kwiecień 1998, s. 1.

${ }^{26}$ B. J. Cohen, The Future..., s. 180.

${ }^{27}$ Należy podkreślić, że ciągle toczy się dyskusja, czy pieniądz elektroniczny jest w ogóle pieniądzem. (Szerzej: P. Marszałek, Polityka pieniężna w świetle zmian w popycie na pieniądz i zmian form pieniądza, [w:] M. Jurek, P. Marszałek, Pieniądz, polityka pieniężna i systemy kursowe. Wspótczesne teorie i rozwiqzania praktyczne, Wydawnictwo AE w Poznaniu, Poznań 2007, s. 53-54).

${ }^{28}$ C. England, Cyberbanking and Currency Competition, paper presented at "The Future of Money in the Information Age", Cato Institute's 14 $4^{\text {th }}$ Annual Monetary Conference, May 23, 1996.

${ }^{29}$ Por. F. A. Hayek, op. cit., s. 95-108; V. C. Smith, op. cit.; L. H. White, The Free Banking..., s. $137-149$. 
zaspokajaniu potrzeb jej mieszkańców w zakresie rozliczeń, płatności i oszczędzania. Przede wszystkim uważa się tu, że pieniądz lokalny sprzyja spójności, poczuciu tożsamości i wzajemnemu wspieraniu się członków danej wspólnoty ${ }^{30}$.

W tym kontekście pieniądz prywatny postrzega się wręcz jako instrument przeciwstawienia się tendencjom globalizacyjnym i neoliberalnym, w których upatruje się niekiedy przyczyn rozpadu społeczności lokalnych na całym świecie. Jak to ujął B. Lietaer, „wszędzie tam, gdzie zaangażowany jest pieniądz państwowy, wspólnoty niszczeją [...] waluty lokalne mają efekt dokładnie odwrotny, budując społeczności”"

Pieniądz lokalny może zatem stanowić swoisty rdzeń i spoiwo danej wspólnoty. Jak stwierdza B. Cohen, lokalne waluty umożliwiają sprawne funkcjonowanie gospodarki o mniejszej skali, lepiej dopasowanej do potrzeb i gustów członków lokalnych społeczności. Pozwalają też zwiększać stopień decentralizacji przez uprzywilejowanie transakcji między podmiotami z tego samego obszaru ${ }^{32}$. Sprzyja to tworzeniu się długotrwałych więzi i interakcji społecznych, zatem w swoisty sposób łagodzi twarde wymogi gospodarki rynkowej. Konkurencja walutowa umożliwia zatem stworzenie lub/i wybór jednostki pieniężnej najlepiej dopasowanej do potrzeb konkretnej wspólnoty. Można ją zatem w tym kontekście postrzegać jako swoiste narzędzie ograniczania roli państwa i decentralizacji sfery pieniężnej.

Zarysowuje się tu więc pewnego rodzaju sprzeczność. $Z$ jednej strony, postrzega się konkurencję walutową na płaszczyźnie subnarodowej jako instrument zwiększenia efektywności gospodarki rynkowej, a także jako wyraz tendencji liberalnych, czy wręcz libertariańskich. $Z$ drugiej natomiast strony, może ona poprzez rozwój systemów pieniądza lokalnego - prowadzić do wyeliminowania negatywnych stron gospodarki wolnorynkowej, globalizacji i dominacji rynków finansowych.

Odmiennie kształtują się procesy konkurencyjne w odniesieniu do drugiej formy pieniądza prywatnego, a mianowicie pieniądza elektronicznego ${ }^{33}$. Pieniądz ten powstaje w określonym środowisku, jednak w przeciwieństwie do pieniądza lokalnego, jego stosowanie nie natrafia na żadne ograniczenia terytorialne. Potencjalnie, pieniądz ten może rozprzestrzenić się na całą gospodarkę światową, znaj-

${ }^{30}$ Szerzej: E. Helleiner, Think Globally, Transact Locally: Green Political Economy and the Local Currency Movement, „Global Society” 2000, no. 14, s. 35-51.

${ }^{31}$ B. Lietaer, op. cit., s. 187.

32 B. Cohen, The Future..., s. 184.

${ }^{33}$ Zgodnie z definicją Banku Rozrachunków Międzynarodowych w Bazylei, pieniądzem elektronicznym jest niemożliwy do śledzenia anonimowy instrument płatniczy na okaziciela, pozwalający na łatwą zapłatę dowolnej innej osobie, w każdych warunkach, bez uczestnictwa pośredników (Survey of Electronic Money Developments, Committee on Payment and Settlement Systems, BIS, Bazylea 2001, s. 1-2). 
dując na przykład powszechne zastosowanie w finansowaniu transakcji w Internecie. Stąd konsekwencje istnienia pieniądza elektronicznego dla skali i nasilenia konkurencji walutowej dalece wykraczają poza płaszczyznę narodową.

Niewątpliwie, pieniądz elektroniczny może stanowić bardzo poważną konkurencję dla narodowych jednostek pieniężnych. Znamienne jest przy tym, że, jak akcentuje W. Wriston, każdy może ogłosić emisję własnej prywatnej, elektronicznej jednostki pieniężnej, a następnie przekonać ludzi, że ma ona wartość i że posługiwanie się nią może być korzystne. Zatem, zdaniem tego autora, pojawił się swoisty nowy standard pieniądza - standard informacyjny (The Information Standard $)^{34}$.

Póki co, nie powstał jednak powszechnie akceptowany pieniądz tego typu. Ponadto, na co zwraca uwagę B. J. Cohen, liczba prywatnych walut tego typu będzie ograniczona $z$ uwagi na względy ekonomii skali, narzucającej niejako to, że $\mathrm{w}$ obiegu będzie znajdować się raczej mniej niż więcej walut ${ }^{35}$. By dany rodzaj pieniądza elektronicznego stał się atrakcyjny, jego sieć musi być duża. To zaś będzie możliwe tylko przy relatywnie małej liczbie takich pieniędzy ${ }^{36}$.

\section{KONSEKWENCJE KONKURENCJI WALUTOWEJ}

Nasilanie się konkurencji walutowej pociąga za sobą różnorodne, często bardzo poważne konsekwencje. Przede wszystkim, zmienia się koncepcja tzw. przestrzeni monetarnej (monetary space) ${ }^{37}$. Mianowicie, w wyniku konkurencji walutowej następuje swoista „deterytorializacja” pieniądza. W coraz mniejszym stopniu pieniądz jest powiązany $z$ danym obszarem - najczęściej obszarem danego państwa. Przestrzeń monetarna zatem coraz rzadziej może być utożsamiana z tym ostatnim.

W tym kontekście, jak podkreśla E. Helleiner, konkurencja walutowa stanowi poważne zagrożenie dla walut narodowych. Kompetencje rządów danych państw w zakresie kontroli stosunków pieniężnych na ich własnym terytorium maleją ${ }^{38}$. Charakterystyczne jest przy tym, że stanowi to rezultat procesów zachodzących zarówno na płaszczyźnie narodowej, jak i subnarodowej. O ile jednak, jak już

${ }^{34}$ W. Wriston, Dumb Network and Smart Capital, „Cato Journal” 1998, vol. 17, no. 3, s. 339.

${ }^{35}$ Autor ten nawiązuje tu do tego, że pieniądz stanowi dobro sieciowe - korzyści z jego stosowania rosną wraz z wielkością jego obiegu i liczbą podmiotów, chcących korzystać z tego pieniądza.

${ }^{36}$ B. Cohen, The Future..., s. 191-192.

${ }^{37}$ Przez przestrzeń tę rozumie się obszar w sensie fizycznym (konkretne terytorium), jak również w sensie wirtualnym (jako specyficzny rynek), wewnątrz którego pieniądz wypełnia swoje funkcje.

${ }^{38}$ E. Helleiner, Conclusion..., s. 215-216. 
wspominano, z konkurencją ze strony innych walut rządy i władze monetarne poszczególnych państw stykają się, na mniejszą bądź większą skalę, w zasadzie nieustannie, o tyle konkurencja ze strony pieniądza prywatnego jest zjawiskiem znacznie mniej rozpoznanym.

Tymczasem coraz szersze rozpowszechnienie pieniądza prywatnego może stanowić prawdziwe wyzwanie dla narodowych władz monetarnych. Jak podkreśla B. J. Cohen, większość rządów straciła już swój tradycyjny monopol terytorialny, wskutek większego wyboru po stronie popytu na pieniądz. Współcześnie poszczególne państwa, wraz z nasilaniem się konkurencji walutowej, tracą dominację także po stronie podażowej ${ }^{39}$.

Oczywiście, trudno się spodziewać, by pieniądz prywatny mógł, przynajmniej w krótkim horyzoncie czasowym, całkowicie zastąpić pieniądz państwowy we wszystkich jego funkcjach. Jak się wydaje, głównej przeszkody w upowszechnieniu pieniądza prywatnego można upatrywać $\mathrm{w}$ chęci zachowania istniejącego status quo. Ponadto należy pamiętać, że upowszechnianie się jakiegoś systemu pieniądza lokalnego i nadawane temu znaczenie różni się w zależności od punktu widzenia. Dla mieszkańców danej wspólnoty czy uczestników jakiejś platformy handlu sieciowego, a więc w skali mikro, znaczenie to jest bardzo duże. Natomiast niekoniecznie musi tak być (i na ogół nie jest) dla władz monetarnych. $Z$ ich punktu widzenia wpływ ten często jest marginalny ${ }^{40}$.

Niemniej systemy pieniądza lokalnego i elektronicznego wywierają niewątpliwie wpływ na kształt i funkcjonowanie systemu pieniężnego. Stają się one przy tym coraz lepiej przystosowane do spełniania wielu funkcji pieniądza, nie tylko funkcji środka płatniczego. Co więcej, po przekroczeniu pewnego progu ilościowego, może okazać się, że poszczególne rodzaje prywatnego stanowią łącznie znaczącą część „oficjalnego” obiegu pieniężnego (czyli obiegu pieniądza, będącego prawnym środkiem płatniczym). Trudno wtedy o dalszy brak reakcji ze strony władz monetarnych.

Z tych względów konkurencja walutowa nie pozostaje bez następstw dla polityki pieniężnej i możliwości kształtowania poziomu cen przez banki centralne. Podmioty te, wskutek opisanych zjawisk, zostają skonfrontowane ze swoistym „wypływem" z obiegu pieniężnego, co będzie równoznaczne, w przypadku braku odpowiednich dostosowań, z utratą kontroli nad częścią procesów gospodarczych ${ }^{41}$.

${ }^{39}$ B. J. Cohen, The Future..., s. 179.

${ }^{40} \mathrm{Co}$ więcej, w pewnych przypadkach banki centralne zachęcały wręcz społeczności lokalne do tworzenia pieniądza lokalnego jako instrumentu wsparcia socjalnego, skierowanego selektywnie do pewnej społeczności, bez konieczności przeformułowywania bądź narażania na szwank całej polityki pieniężnej (B. Lietaer, op. cit., s. 226).

${ }_{41}$ Jak ujmuje to B. J. Cohen, „wraz ze wzrostem liczby [systemów pieniądza prywatnego P. M.], te darwinowskie zmagania nawet bardziej przybiorą na sile, w coraz większym stopniu 
Mechanizm ten wyjaśnia B. J. Cohen. Przede wszystkim zaburzeniu ulega relacja nominalnego popytu i podaży krajowego pieniądza - prawnego środka płatniczego. Bank centralny nadal może wpływać na cenę i podaż tego pieniądza, ale społeczeństwo ma też swobodny dostęp do innych rodzajów pieniądza, którymi może się posługiwać we wzajemnych transakcjach (lub utrzymywać w nim oszczędności). Wszystkie tego typu „substytucyjne” waluty składają się na alternatywny obieg pieniężny, w pewnym stopniu wpływający na wielkość zagregowanego popytu. Wpływ ten jest tym większy, im większa rola pieniądza prywatnego $\mathrm{w}$ danej gospodarce ${ }^{42}$. Jednocześnie, wskutek dostępnych alternatywnych form pieniądza maleje popularność gotówki, jak również zgłaszany przez banki popyt na rezerwy pieniądza państwowego w banku centralnym.

Tym samym bank centralny, który poprzez zmiany stóp procentowych ${ }^{43}$ próbuje oddziaływać na zagregowany popyt, a przez to na poziom cen, może natrafić na poważne ograniczenie skuteczności swojej polityki. Kształtowanie rynkowych stóp procentowych przez bank centralny jest możliwe tylko wtedy, gdy zachowuje on monopol na ostateczny środek rozliczeń, czyli pieniądz państwowy, będący prawnym środkiem płatniczym ${ }^{44}$. W wyniku tego monopolu bank centralny dysponuje swoistą „ „źwignią”, za pomocą której może wpływać na transakcje na rynku finansowym, a przez to uruchamiać transmisję impulsów monetarnych poszczególnymi kanałami ${ }^{45}$.

W następstwie konkurencji walutowej i związanych z nią procesów monopol ten wydaje się jednak coraz bardziej wątpliwy. Nie chodzi tu przy tym tylko o fakt, że bank centralny nie może kontrolować podaży pieniądza gotówkowego i rezerw bankowych, które utrzymuje na rachunkach banków. Problemem jest też to, że obie kategorie odgrywają coraz mniejszą rolę w gospodarce. Jak to bowiem ujmuje B. Friedman, „bycie monopolem ma niewielką wartość, jeżeli nikt nie potrzebuje, czy nawet nie chce posiadać tego, co stanowi o monopolu" ${ }^{46}$.

umniejszając rolę państwa w zarządzaniu sprawami monetarnymi” (B. J. Cohen, The Future..., s. 186).

${ }^{42}$ Por. B. J. Cohen, The Future..., s. 195.

${ }^{43}$ Stopy procentowe są współcześnie podstawowym instrumentem polityki pieniężnej.

${ }^{44}$ Monopol ten wynika z wyłącznego prawa emisji pieniądza gotówkowego oraz faktu, że żaden inny uczestnik procesów rynkowych nie może zwiększać ani zmniejszać całkowitego wolumenu rezerw. Natomiast bank centralny ma możliwość nałożenia na banki rezerw minimalnych, a także organizuje i odgrywa główną rolę w mechanizmie rozliczeń (B. M. Friedman, Decoupling at the Margin: the Threat to Monetary Policy from the electronic Revolution in Banking, „International Finance" 2000, vol. 3 (2), s. 261-262).

${ }^{45}$ Zob. np. C. Borio, The Implementation of Monetary Policy in Industrial countries: A Survey, BIS Economic Papers no. 47, Bazylea 1997.

${ }^{46}$ B. M. Friedman, The Future of Monetary Policy: The Central Bank as an Army with Only a Signal Corps?, „International Finance” 1999, vol. 2 (3), s. 327. 
W skrajnym przypadku waluta banku centralnego może w ogóle przestać liczyć się w gospodarce, co S. Kobrin nazywa „nadejściem nowego dnia dla władz monetarnych". Co więcej, zdaniem tego autora problemy mogą wystąpić nie tylko w realizacji polityki pieniężnej, ale nawet w pomiarze i zdefiniowaniu kategorii monetarnych ${ }^{47}$. Coraz bardziej bowiem zacierają się różnice między prawnym środkiem płatniczym a rozmaitymi aktywami prywatnymi, pełniącymi funkcje pieniądza.

$\mathrm{Z}$ poglądem tym nie zgadza się E. Helleiner, według którego można mówić co najwyżej o „fałszywym świcie”. W opinii tego autora jest raczej nieprawdopodobne, by nowe formy pieniądza stanowiły znaczące zagrożenie dla władz monetarnych ${ }^{48}$.

Niezależnie od tych dość skrajnych poglądów, można uznać, że sprostanie konkurencji walutowej stanowi niewątpliwe wyzwanie dla banków centralnych. Stąd celowe wydaje się monitorowanie przez te instytucje zmian zachodzących w systemach pieniężnych, a także odpowiednie dostosowywanie instrumentarium polityki pieniężnej.

\section{ZAKOŃCZENIE}

Procesy konkurencji walutowej nasilają się we współczesnej gospodarce. W coraz większym stopniu zachodzi to na płaszczyźnie subnarodowej. Poszczególne waluty narodowe muszą sprostać swoistej presji już nie tylko ze strony walut innych państw, ale także ze strony rozmaitych, bardzo różnorodnych systemów pieniądza prywatnego (elektronicznego i lokalnego).

Można przyjąć, że w najbliższych latach trudno jeszcze spodziewać się, by waluty narodowe miały ustąpić miejsca w hierarchii pieniężnej nowym odmianom pieniądza. Niemniej, można wyobrazić sobie sytuację, w której monopol ze strony władz monetarnych zostanie przełamany. Co godne podkreślenia, wcale nie musi to oznaczać gorszego funkcjonowania systemów pieniężnych. Dominujące obecnie rozwiązania w zakresie organizacji tych systemów nie przyniosły bowiem znaczącego efektu jakościowego i ilościowego.

${ }^{47}$ S. Kobrin, Electronic Cash and the End of National Markets, „Foreign-Policy” 1997, no. 107, s. 65-77. Jest to zatem sytuacja będąca swojego rodzaju odpowiednikiem dolaryzacji - prawny środek płatniczy może także zostać wyparty z funkcji pieniądza. W przeciwieństwie do tego procesu, dzieje się tak jednak nie wskutek wzrostu znaczenia innej waluty narodowej, ale jakiegoś typu pieniądza prywatnego.

${ }^{48}$ E. Helleiner, Electronic Money: A Challenge to the Sovereign State?, "Journal of International Affairs" 1998, vol. 51, no. 2, s. 399-400. 
Warto też podkreślić, że rezygnacja $\mathrm{z}$ waluty narodowej może w pewnych przypadkach być wymuszona przez procesy konkurencyjne, ale może też stanowić świadomy wybór władz danego kraju. Określone państwo może bowiem niejako przyłączyć się do partnera z silniejszą walutą. Możliwe jest także wspólne wykreowanie przez grupę państw nowej jednostki pieniężnej. Zawsze bowiem tam, gdzie występuje konkurencja, pojawia się także pole do współpracy.

\section{CURRENCY COMPETITION AND ITS CONSEQUENCES}

SUMMARY

The aim of the paper is to present processes of currency competition in contemporary economics. The problem is of special importance, because such competition has recently intensified to a large degree, mainly due to significant changes in monetary systems around the world. Moreover, currency competition is a multidimensional process that brings serious consequences for states, their citizens and central banks as well. In the second point definitions of currency competition are presented, as well as its features and dimensions. The third point characterizes the most controversial area of currency competition, namely rivalry between public and private monies, whereas the fourth one - focuses on the consequences of competition between different monetary units. 
